\title{
Rosalyn Yalow (1921-2011): Madame Curie from the Bronx
}

Siang Yong $\underline{\operatorname{Tan}^{1}}$, MD, JD, Adam $\underline{\text { Bracha }}^{2}$, MD

$\mathrm{R}$ osalyn Sussman Yalow was a capable stenographer. Were it not for her perseverance and a series of fortuitous events, this Nobel Prize-winning scientist might have remained a secretary of unusual research talent. She would not have discovered the technique of radioimmunoassay, and many important mysteries of nature might have remained mysterious. But Yalow did persevere. "Perhaps the earliest memories I have are of being a stubborn, determined child," she recalled in her autobiography. "Through the years, my mother has told me that it was fortunate that I chose to do acceptable things, for if I had chosen otherwise, no one could have deflected me from my path."

The story of her chosen path is a fascinating one. Yalow was born on 19 July 1921 in New York City, New York, United States, where she would live for all but three years of her life. Her parents were Jewish immigrants from Eastern Europe. She learnt to read before entering kindergarten; in public school, her first love was mathematics, and as a high school student, she loved chemistry. After graduating high school at 15 years of age, she enrolled at Hunter College, where her passion changed to physics. She was fascinated by Eve Curie's biography of her Nobel Prize-winning mother, Marie Curie, and recalled "hanging from the rafters" with excitement after hearing a guest lecture on nuclear fission by Enrico Fermi. In 1941, she graduated with degrees in physics and chemistry, hoping to pursue a career in

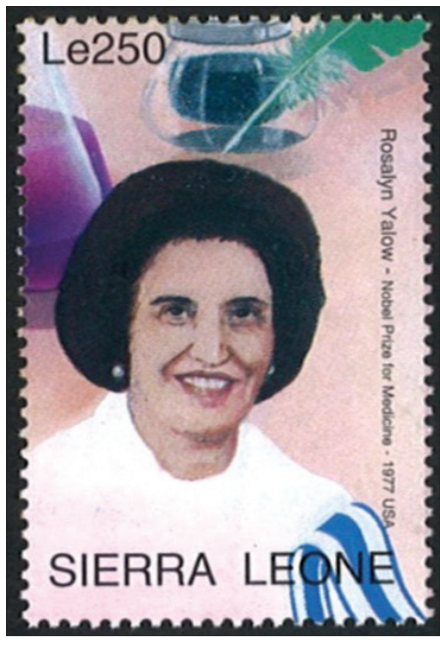
nuclear physics.

COLD SHOULDER Yalow wanted to attend medical school, but her family encouraged her to become an elementary school teacher - an idea she opposed. Graduate school was another option, but she felt it was unlikely that any good graduate school would offer financial support for a woman in physics. Nevertheless, she submitted applications to several universities, all meeting with prompt rejection. One response was particularly blunt: "She is from New York. She is Jewish. She is a woman." With few other options, Yalow enrolled in stenography courses and took a part-time position as a secretary.

As secretary to Rudolf Schoenheimer, a leading biochemist at Columbia University, Yalow was tantalisingly close to academe. Her dreams were realised when, shortly after starting her secretarial duties, she was offered a graduate student position and teaching assistantship in physics at the University of Illinois. "It was an achievement beyond belief," she recalled. "I tore up my stenography books" and moved to Urbana-Champaign, Illinois.

At the University of Illinois, she was the first female graduate student in physics in nearly 40 years. Had World War II recruitment not winnowed the ranks of young male graduate students, she might never have been accepted. She faced scepticism as the lone woman among the 400 faculty members of the College of Engineering. She recalled: "I was delighted to receive a straight $A$ in two of the courses, an $A$ in the lecture half of the course in Optics and an A- in its laboratory. The chairman of the Physics Department, looking at this record, could only say 'That A-confirms that women do not do well at laboratory work. '" Nonetheless, Yalow thrived. She also met Aaron Yalow, a fellow physics graduate student, who would become her husband in 1943. They had two children, Benjamin and Elanna, and were married until his death in 1992

DYNAMIC DUO After receiving her PhD in physics in 1945, Yalow returned to New York with her family, and secured a teaching position at her alma mater. During this time, she was intrigued by the research of George de Hevesy, a Hungarian chemist who won the Nobel Prize in 1943 for his research on the use of tracer radioisotopes in the study of chemical processes. To pursue this interest, she joined the nascent Radioisotope Service at the Bronx VA (Veterans Administration) Medical Centre in 1947. In 1950, she left her teaching duties to work full-time at the VA hospital. Solomon A Berson, a senior internal medicine resident, joined her. In their laboratory, converted from a cramped janitor's closet, Yalow and Berson would begin the research that led to their discovery of the radioimmunoassay technique. They worked together for the next 22 years, alternating first authorship on the papers they published. After Berson's passing in 1972, Yalow requested that their VA laboratory be renamed the Solomon A Berson Research Laboratory.

DARING HYPOTHESIS Yalow and Berson's first investigations involved the application of radioisotopes to blood volume determination, diagnosis of thyroid diseases, and the kinetics of iodine metabolism. With time, their research extended to studies of the distribution of globulins and other serum proteins. They focused on insulin, a small peptide that was readily available

${ }^{1}$ Emeritus Professor of Medicine, ${ }^{2}$ Research carried out during transitional residency, John A Burns School of Medicine, University of Hawaii, Honolulu, USA Correspondence: Prof Tan Siang Yong, 2226 Liliha Street, Suite B-104, Honolulu, HI 96817, USA. siang@hawaii.edu 
in a highly purified form. It was a hormone of particular interest to Yalow, whose husband was a diabetic. In the 1950s, bovine insulin was used to treat diabetes mellitus, but scientists knew that patients developed resistance to it over time. Yalow and Berson hypothesised that the foreign insulin stimulated the production of antibodies. To study this, they first tagged molecules of bovine insulin with radioactive iodine. After injecting trace amounts into diabetic and non-diabetic volunteers, they then measured radioactivity in serial blood specimens. Clearance of the tagged insulin molecules was slower in the diabetic cohort. Further analysis showed that serum globulins had bound the radiolabelled insulin, confirming their hypothesis. The significance of the experiment was threefold. First, they demonstrated an underlying cause of resistance to bovine insulin. Second, they showed that a peptide as small as insulin could generate an immune response. Third, they demonstrated this finding using a novel new technique, which they termed 'radioimmunoassay'.

Never before had radioisotopic techniques been used to demonstrate the primary reaction between antibodies and antigens in solution. Alternative techniques employed secondary measures that required a visible reaction, such as the precipitation or agglutination of antigen-antibody complexes. Radioimmunoassay allowed for detection of far smaller quantities of antigen than these methods.

Like many of Yalow's earlier endeavours, her findings were greeted with considerable scepticism. The original paper was rejected by Science and initially rejected by the Journal of Clinical Investigation with the following critique: "The dogmatic conclusions set forth... are not warranted by the data. The experts in this field have been particularly emphatic in rejecting your positive statement that the 'conclusion that the globulin responsible for insulin binding is an acquired antibody appears to be inescapable.' They believe you have not demonstrated an antigen-antibody reaction on the basis of adequate criteria, nor that you have definitely proved that a globulin is responsible for insulin binding, nor that insulin is an antigen." But again, Yalow persevered, and the findings were eventually published in 1959. In the years that followed, radioimmunoassay would become an essential tool for researchers across the full spectrum of biological sciences.

EGALITARIAN CONVICTIONS The list of honours and awards Yalow accepted during her illustrious career is long. She received, among other awards, the American Medical Association Scientific Achievement Award in 1975, the Nobel Prize in 1977 and the National Medal of Science in 1988. She was inducted into the National Academy of Sciences, the New York Academy of Sciences, the American College of Nuclear Physicians and several others. She was also selected for the 1978 Ladies' Home Journa/ Woman of the Year award, an honour she declined. In a letter to the magazine's editor, Yalow wrote: "It is inconsistent and unwise to have awards restricted to women or to men in fields of endeavour where excellence is not clearly sex-related." In her Nobel banquet speech, she exhorted women to "believe in ourselves or no one else will believe in us... the world cannot afford the loss of the talents of half its people if we are to solve the many problems that beset us."

Yalow also felt strongly that her discovery should be applied as widely and freely as possible. She did not patent the radioimmunoassay technique, nor did she consult for the biomedical industry. Despite its enormous commercial potential, she said: "we never thought of patenting RIA (radioimmunoassay). Patents are about keeping things away from people for the purpose of making money. We wanted others to be able to use RIA."

MEDICAL GIANT, MEDICAL VICTIM It happened four years after Yalow's mandatory retirement from the VA hospital at the age of 70 and three years since the passing of her husband. She was rushed by ambulance to a nearby university hospital. She had lectured there on several occasions, and the university had awarded her an honorary degree. "The house officer in the emergency room didn't remember her name," recalled Yalow's friend and fellow physician Eugene Straus. "But he remembered a rather dirty old lady who had suffered a stroke. They refused to admit her... she had been 'dumped.' " The Nobel Prize-winning scientist, unconscious and unrecognised after suffering an ischaemic stroke, was then transferred to a second hospital for admission. Yalow regained consciousness after five days and left the hospital two weeks later. She would go on to live until the age of 90, dying on 30 May 2011.

\section{BIBLIOGRAPHY}

- Cleve PT, Nobelstiftelsen. Les Prix Nobel. Stockholm: Imprimerie Royale; 1978.

- Hessel CS. Blessed is the Daughter. Rockville, MD: Shengold Books, 1999.

- Holden C. Yalow Declines Ladies' Award. Science 1978; 200:1464-5.

- Kahn CR, Roth J. Berson, Yalow, and the JCl: the agony and the ecstasy. J Clin Invest 2004; 114:1051-4.

- Lindsten JE, Nobelstiftelsen. Physiology or medicine, 1971-1980. Singapore: World Scientific, 1992.

- Straus E. Rosalyn Yalow, Nobel Laureate: Her Life and Work in Medicine: a Biographical Memoir. New York, NY: Plenum Trade, 1998. 